\title{
Article \\ Eco-Anxiety and Pastoral Care: Theoretical Considerations and Practical Suggestions
}

\author{
Panu Pihkala (ii)
}

check for updates

Citation: Pihkala, Panu. 2022 Eco-Anxiety and Pastoral Care: Theoretical Considerations and Practical Suggestions. Religions 13: 192. https://doi.org/10.3390/ rel13030192

Academic Editors: Pamela R. McCarroll and HyeRan Kim-Cragg

Received: 31 January 2022

Accepted: 18 February 2022

Published: 23 February 2022

Publisher's Note: MDPI stays neutral with regard to jurisdictional claims in published maps and institutional affiliations.

Copyright: (C) 2022 by the author. Licensee MDPI, Basel, Switzerland. This article is an open access article distributed under the terms and conditions of the Creative Commons Attribution (CC BY) license (https:// creativecommons.org/licenses/by/ $4.0 /$ )
Faculty of Theology, HELSUS Sustainability Science Institute, University of Helsinki, P.O. Box 4, 00014 Helsinki, Finland; panu.pihkala@helsinki.fi

\begin{abstract}
The environmental crisis is producing an increasing number of both physical and psychological impacts. This article studies the challenge of eco-anxiety for pastoral care, drawing from both interdisciplinary research and ecological theology. The aim is to help both practitioners and researchers to encounter eco-anxiety more constructively. The rapidly growing research about ecoanxiety and therapy is discussed in relation to pastoral care. The various forms of eco-anxiety are briefly analyzed. The role of the caregivers is discussed by using sources that study the challenges of therapists in relation to eco-anxiety. The existential depths of eco-anxiety are probed in the light of recent research and older existentialist theory. It is pointed out that the political character of ecological issues, especially climate change issues, causes many kinds of challenges for pastoral care. As the constructive conclusion of the article, various possibilities and resources for encountering eco-anxiety in pastoral care are discussed, along with the connections with wider pastoral theology. It is argued that pastoral care providers should engage in self-reflection about their own attitudes and emotions related to ecological issues, preferably with the support of trusted peers or mentors. Various organizational developments are also needed to support caregivers. Dialectical thinking is one tool that can help to navigate the complex dynamics related to environmental responsibility, eco-emotions, and questions of hope or hopelessness.
\end{abstract}

Keywords: eco-anxiety; pastoral care; climate anxiety; pastoral theology; spiritual care; psychology; existentialism; eco-theology; ecological grief; therapy

\section{Introduction}

"It's in those bleak, liminal times before dawn that the eco-anxiety hits hardest. I lie in bed praying, desiring with all my heart that there be a future; that I might have again that taken-for-granted confidence that I'll live to see grandchildren, great-grandchildren. Now young people are deciding not to have children at all" (Personal reflections by Anglican theologian Frances Ward; Ward 2020, p. 141).

The concept "eco-anxiety" refers to a variety of difficult emotions and mental states that are significantly related to environmental problems, while "climate anxiety" refers to the climate-change-related forms of eco-anxiety (for discussion about terminology, see Pihkala 2020a; Wardell 2020). Some people felt eco-anxiety already decades ago (Clinebell 1996, pp. 13-14, 31-32), but it is currently an increasingly widespread phenomenon. For example, a recent global survey about climate change among 10,000 children and youth in 10 countries revealed that $56 \%$ of them thought that "humanity is doomed", while $75 \%$ felt the climate future to be frightening; $42 \%$ reported having felt at least some hesitation in having children because of the climate crisis (Hickman et al. 2021).

Even amidst the COVID-19 pandemic, climate concerns and worries are very high (Pew Research Center 2021). Worry and anxiety can be separated technically from each other, but in relation to climate change and other ecological problems, these mental phenomena are deeply connected (Ojala et al. 2021). People may feel climate-related fear, anxiety, and worry because of many kinds of things, for example, the uncertainty of the 
future, the damage that has already been done to ecosystems and social systems, changes in identities and lifestyles, and the loss of hope and dreams (for various kinds of climaterelated loss, see Tschakert et al. 2019). Some people recognize these feelings as related at least partly to the climate crisis, while some people try to avoid making that link for various reasons such as group pressure or internal psychological anguish (for climate denial as a coping mechanism, see Haltinner and Sarathchandra 2018). Thus, there is both explicit and implicit climate anxiety (cf. Weintrobe 2021; LaMothe 2021a).

Eco-anxiety and climate anxiety have received growing attention in public discussions and research. There are disputes about what terms would be the best and about the framing of these phenomena, but even more fundamentally, there is a growing concern about the resilience of people amidst the growing ecological damage (see, e.g., Cunsolo et al. 2020). It seems evident that varieties of eco-anxiety will increasingly feature in the lives of people who seek pastoral care support or, more widely, spiritual care. This provides many challenges and possibilities. How will providers of pastoral care frame eco-anxiety-as mainly a mental health issue or as a broad phenomenon that also includes action tendencies and moral emotions? Will providers of pastoral care show care and recognition to people who feel eco-anxiety? What kind of methods will they use, and what ways forward will they offer people?

In this article, the challenges and potentials of pastoral care in relation to eco-anxiety are studied from an interdisciplinary perspective. Theological reflection is included, but a major focus in the article is the application of the contemporary interdisciplinary research about eco-anxiety and eco-emotions into pastoral care. Recent research and discussion from related fields are briefly introduced, and needs for further research and discussion are pondered. A special emphasis is given to the application of the emerging literature about therapy and eco-anxiety into pastoral care. While some scholars, including the author of this article, have made observations about eco-anxiety in the context of pastoral theology and pastoral care, as a whole, this subject has received relatively little attention (see Calder and Morgan 2016; Clinebell 1996; Pihkala 2016a, 2020b; LaMothe 2019, 2020, 2021a; McCarroll 2020; Helsel 2018; LaMothe 2016, 2021b, 2021c).

The structure of the article is as follows. First, the multifaceted character of eco-anxiety is briefly analyzed by using interdisciplinary research sources. It is argued that caregivers should be able to recognize that there may be various manifestations of eco-anxiety, both paralyzing and adaptive. Second, three major challenges and potentials for pastoral care in relation to eco-anxiety are delineated: the role of the caregivers, the existential depth of the issue, and the political dimensions of the issue.

It is pointed out that research about therapists shows the difficulty of caregivers to respond constructively to eco-anxiety: inner work and social support are needed to build resources for encounters and to enable a personal process to move forward, which will support efforts to help others.

The existential depth of eco-anxiety provides both challenges and possibilities for pastoral care: people are grappling with issues related to the meaning of life, finitude, and responsibility. Belief systems can help to provide existential resilience, but this requires an approach that takes the existential questions seriously and does not offer too-easy hope or too-easy redemption.

The political character of climate issues challenges caregivers and pastoral theologians to engage with their own attitude towards political participation. Pastoral theologians who are sensitive to eco-anxiety, such as Ryan LaMothe, Pamela McCarroll, and Storm Swain, have argued that pastoral theologians have a vocation to address the sources of suffering, which means engaging with politics and climate action. Furthermore, pastoral care providers need sensitivities to analyze the socio-political factors which affect people's eco-emotions. Intersectional justice issues also affect eco-anxiety.

In the final part of the article, many possibilities and resources for pastoral care in relation to eco-anxiety are discussed. These include the role of emotional skills and the possibility to draw from various kinds of therapies and psychologies. Special attention is 
given to eco-psychology and dialectical thinking, which can help to navigate the complex dynamics related to the topic, such as the relationship between individual environmental responsibility and structural issues or the relationship between hope and hopelessness. The connections between wider pastoral theology and ecological theology bring out the possibilities to encounter eco-anxiety constructively in education, environmental action, and ritual or spiritual practices. Various organizational developments are also needed to support caregivers, such as the inclusion of teaching related to eco-anxiety in theological seminaries and universities. A table is provided about the key results of the article: the various possibilities and learning goals in relation to eco-anxiety and pastoral care.

\section{Eco-Anxiety: Practical, Paralyzing, and Existential}

The term anxiety is notoriously wide-ranging (Barlow 2004; LeDoux 2016). Many health professionals use it in the connotation of anxiety disorders. Philosophers and theologians tend to use the term in the connotation of existential angst: anxiety about the human condition, and yet further, emotion researchers point out that anxiety is also an emotion that arises in relation to potential threats, which include some kind of problematic uncertainty from the point of view of the individual (Kurth 2018).

When interdisciplinary research about anxiety and the ecological crisis is evaluated, it can be discerned that the word anxiety is used in all of these connotations in relation to eco-anxiety (Pihkala 2020a). Eco-anxiety can manifest as strong anxiety, and it can be paralyzing (e.g., Clayton 2020; Taylor 2020); sometimes, the philosopher Glenn Albrecht's (Albrecht 2011) concept of "eco-paralysis" is used to refer to the paralyzing form (see also Albrecht 2019). Existential psychologists, philosophers, and theologians have increasingly written about the dimensions of eco-anxiety that have the characteristics of existential anxiety: people are grappling, for example, with questions of freedom and guilt, and meaning and meaninglessness, in relation to the vast ecological crisis (e.g., Budziszewska and Jonsson 2021; Pihkala 2018a), and in interdisciplinary research, it has been increasingly noticed that eco-anxiety does include the motivational dimension. Using anxiety philosopher Charlie Kurth's terminology about practical anxiety, Pihkala (2020a, 2020c) has called this dimension "practical eco-anxiety". It is practical and adaptive because it stems from the perception of real problems that need attention. Challenges arise because these socioecological problems are so difficult to solve and they require international cooperation; individuals and even groups can easily feel relatively powerless, which easily increases the feelings of uncontrollability which intensify anxiety (for these anxiety dynamics, see Grupe and Nitschke 2013).

Eco-anxiety research is currently growing rapidly, but so far, this research has mainly concentrated on the more paralyzing forms of eco-anxiety. This can easily strengthen the view of eco-anxiety as something at least nearly pathological, but scholars increasingly oppose this kind of emphasis, pointing out the adaptive fundamental character of ecoanxiety (Hickman et al. 2021; see also, e.g., Wullenkord et al. 2021; Verplanken et al. 2020). Among pastoral theologians, LaMothe (2020) has observed the various possibilities of eco-anxiety, both the paralyzing and the motivating ones (see also LaMothe 2021a).

Eco-anxiety is related to numerous phenomena and factors because it is connected with reacting to the ecological crisis and all the related social complexity (Crandon et al. 2022). There are many psychological phenomena that share at least some aspects with eco-anxiety, such as ecological trauma or climate trauma (Pihkala 2020d; Woodbury 2019), coping and adapting to the ecological crisis (e.g., Bradley and Reser 2017; Doherty and Clayton 2011), and various emotions and feelings related to these processes (e.g., Pihkala 2022a; Hamilton 2020; Albrecht 2019). Among the emotions and feelings, some have received special attention, such as grief or sadness (e.g., Comtesse et al. 2021; Cunsolo Willox and Landman 2017), guilt and/or shame (e.g., Jensen 2019; Fredericks 2021), and anger and/or rage (e.g., Antadze 2020). Because of the complex social dynamics related to these issues, scholars have argued that a psychosocial view would be highly necessary (e.g., Andrews and Hoggett 2019; see also the social psychology approaches in, e.g., Clayton and Manning 2018). 
In a recent article, the theological and spiritual literature related to eco-anxiety prior to 2020 is briefly reviewed (Pihkala 2020b). New writings on related topics appear regularly, and many of these are cited below (e.g., Malcolm 2020a, 2020b; Ward 2020; Joyce 2020; see also the reflections about ecological trauma and pastoral theology in Swain 2020). Most of the sources discussing spiritual care and eco-anxiety have focused on Christianity, but there is an article about Hindu spiritual care and climate trauma (Patel 2020).

Pastoral care providers need support and information so that they can see the various dimensions of eco-anxiety and not just one or two of them. Seeing the fundamental role of eco-anxiety as practical anxiety helps to avoid pathologization and over-therapization, and seeing the possibilities of eco-anxiety to turn into a paralyzing condition helps to understand the importance of providing enough psychosocial and spiritual support for people.

\section{The Role of the Caregivers}

A crucial challenge is the resilience and attitudes of the caregivers (in this case, the pastoral care providers). In relation to caregivers in general, it has been increasingly noted that the ecological crisis is a psychologically demanding topic for them, too. The sheer weight and intensity of the crisis are difficult to bear (if proof is needed, the natural sciences offer plenty of data and predictions; see, e.g., Steffen et al. 2015). The issue is made more difficult by the fact that everyone is implicated in the crisis: the topic challenges people's behavioral habits, their values, their identities, their beliefs, and their dreams about the future. Furthermore, people may already have so many other difficulties in their lives that it is challenging to give any resources to the ecological issues. As a result of all this complexity, people have been noticed to be prone to distancing reactions, in other words, to disavowal and various other forms of denial. These dynamics can also be analyzed as forms of maladaptive or adaptive coping or as either healthy or problematic defense mechanisms. (The research literature on these topics is very large. For popular introductions, see Stoknes 2015; Marshall 2015. For an academic overview, see Jylhä 2017).

For a long time, the people who felt eco-anxiety had strong difficulties in finding caregivers or therapists who could resonate with their experiences and support them on an emotional level. There are many reminiscences of encounters with therapists who simply have disavowed the reality of the issue and suggested that some inter- or intrapersonal matters are the real cause of the person's feelings (see already Macy 1995; and, e.g., Stoknes 2015). While the inter- and intrapersonal matters may indeed shape people's experiences, there is a large and rapidly growing research evidence showing that eco-anxiety can simply result from knowing and feeling about environmental issues (see Section 2 above).

Currently, there is a growing research literature about the difficulties of therapists in facing ecological issues and especially the climate crisis. Haseley (2019) discusses the relationship between other mental health issues and climate anxiety and observes that the therapists' own disavowal or denial can be a challenging obstacle. Seaman (2016) surveyed how therapists see the role of climate issues and noted that younger therapists recognized climate issues more often in their work, which resulted in the hypothesis that these younger therapists were better able to resonate with their clients' issues related to the climate crisis. Since the time of that study, the climate issues have become even more pressing, and it is probable that they feature also even more in therapy.

In recent research, Silva and Coburn (2022) analyze these dynamics on the basis of eight in-depth interviews of Australian therapists. They make highly useful categorizations of the various difficulties that therapists experience. Topics that are discussed include the challenges for the self-identity and psychological well-being of the therapist, the existential and socio-political challenges included in climate issues, the therapists' experiences of how clients increasingly bring these matters into therapeutic encounters, and many professional challenges and uncertainties that the therapists experience.

The personal actions and attitudes of the therapist in relation to climate action may be evoked in many ways in therapeutic encounters. Clients may expect from the therapist or caregiver a certain kind of attitude towards climate issues, either a positive or a negative 
one. For example, those in disavowal or denial may expect their caregiver to manifest a similar attitude and offer them psychosocial support in their own stance, and others may expect a commitment to climate action manifested by the caregiver.

Furthermore, the therapist or caregiver may himself/herself wrestle with inner conflicts related to climate action, as has been noted in research (Silva and Coburn 2022; cf. Orange 2017). Therapists may feel anxiety because their own lifestyle contributes to climate emissions and because they feel either inner or outer pressure to make changes. This distress may cause many kinds of results: some therapists or caregivers may try to avoid the distressing topic altogether, while others may try to solve the problem by engaging in various kinds of behavior and emotion regulation.

It is to be expected that similar difficulties occur with pastoral care providers. There are some discussions of this dynamic in literature (Pihkala 2016a; McCarroll 2020; LaMothe 2019, 2020, p. 143), but the author is not aware of wider empirical research about eco-anxious people's experiences with pastoral care providers. The fact that so little research and other literature has been published about pastoral care and eco-anxiety-with various termspoints to the probability that many pastoral care providers are struggling to integrate eco-anxiety sensitivity into their work. Many authors have emphasized that much selfcompassion is needed because the situation is indeed difficult (Davenport 2017; Ray 2020; see also Brach 2019).

Pastoral care providers thus need both individual work and social support in order to encounter eco-anxiety constructively. Intention and determination are important (Greenspan 2004), but the contexts of people are very different, and support from others is crucial, too. Below, in Section 6, the possibilities of a dialectical approach are discussed (drawing especially from Lewis et al. 2020), and in Section 7, certain organizational means for support are listed. However, the existential weight of eco-anxiety makes things more difficult and also more pressing, and this theme is discussed next.

\section{The Existential Depth of Eco-Anxiety}

The wording "existential crisis" can be used in two connotations in relation to the climate crisis. First, the term is sometimes used to refer simply to the life-threatening character of this global crisis. For many people, the climate crisis is an existential threat to their very survival or their well-being. Second, the term can be used in the sense of existentialism, referring to the difficult questions and feelings related to being human in a vast universe.

Pioneering scholars and therapists have long since noticed the existential character of eco-anxiety, even while the concept of eco-anxiety was not yet used. The influential therapist Clinebell (1996) discussed the phenomenon with the term angst and observed already in the 1990s many of the emotions which can be connected with it, such as guilt and sadness. Clinebell also noticed the connections between death anxiety and eco-anxiety, although he did not develop this theme fully.

The author has in his studies pointed out that the existential theologian Paul Tillich had much ecotheological content in his works and also briefly discussed some aspects of eco-anxiety, especially the shame and horror which can be related to realizing how strongly humankind has damaged the more-than-human world (see Pihkala 2018a, 2018b; Pihkala 2020b; Tillich 1963). The author also pointed out that the three major aspects of Tillich's view of existential anxiety all apply strongly to eco-anxiety. There is eco-anxiety related to fate and death, to emptiness and meaninglessness, and to guilt and condemnation (Pihkala 2018a; Tillich 1952; see also generally Scott and Weems 2013).

Currently, scholarship is deepening the understanding of the existential character of eco-anxiety. For example, existential psychologists Budziszewska and Jonsson (2021) studied the climate anxiety of 10 Swedish therapy clients and applied the existential theories of Tillich, Irvin Yalom, and Ernesto Spinelli. These researchers observed that people may experience existential isolation in the midst of the climate crisis, and they raise up important aspects related to authenticity, freedom, and responsibility. ${ }^{1}$ The existential depth of eco- 
anxiety has also been noted by many other scholars (e.g., Pienaar 2011; Passmore and Howell 2014; Silva and Coburn 2022).

The dynamics of these existential aspects are wider and more complex than what can be discussed here. Deep down, they seem to be related to the challenge of finding meaning amidst suffering and practicing responsibility without burning out (cf. Pihkala 2018a; Jamail 2019; Clinebell 1996; see also the similar reflections in eco-anxiety books that do not operate with the concept of meaning, such as Gillespie 2020; Ray 2020; Weber 2020). In the following, some aspects of the existential dimensions are discussed in order to provide examples of what kind of issues may be related to pastoral care encounters of eco-anxiety.

As noted above, guilt has been found to be one of the common emotions related to climate issues because so many things in the lifestyles of industrialized countries contribute to global warming. Climate guilt can be so severe that it has an existential dimension: it becomes related to the way in which the person exists in the universe. Climate guilt may also have elements of what existential psychologists such as Rollo May and Irvin Yalom have called existential guilt: people may feel that they are not fulfilling their potential as beings. This feeling of not being what one should or could be comes close to shame, which is another prominent climate emotion (Jensen 2019; Fredericks 2021; Orange 2017). Scholars have noted that there exists "species shame": some people feel shame as members of the human species, which has so profoundly damaged the ecosystems.

These feelings are closely related to many other notions discussed in existentialism, such as freedom and authenticity. They may also be connected with feelings of isolation, another major existentialist theme (Yalom 1980; for climate anxiety and isolation, see Budziszewska and Jonsson 2021). People may feel isolated and lonely in relation to climate issues because of many reasons. One possible reason is guilt and/or shame. Another is that their climate grief is not recognized by others and it turns into disenfranchised grief (Cunsolo Willox and Ellis 2018; Kretz 2017). Yet another reason is simply the experience that others in one's vicinity do not take climate issues seriously, as they practice denial or disavowal (Budziszewska and Jonsson 2021; Weintrobe 2021). "Climate isolation" as a feeling may eventually have elements of existential isolation, the feeling that one cannot find the connection between oneself and the world.

Authenticity is an existentialist concept that has been used in various connotations: it refers to being true to one's being (for a review of various views about it, see Mkono 2020). Here, it is only pointed out that issues of authenticity feature in people's experiences of the climate crisis: the crisis provokes many people to ponder their deepest values and their life choices, and the practical situations amidst the crisis may cause conflicts related to authenticity (see also the brief reflections in Budziszewska and Jonsson 2021). As an example of these, tourism scholar Mkono has analyzed the experiences of authenticity and inauthenticity related to "eco-conscious" travelers and their choices. Often these travelers fail to live up to the moral standards which they espouse, which can raise accusations of hypocrisy. Mkono insightfully points out that these kinds of issues are both social debates and potentially existential distresses: feelings of inauthenticity may reach an existential level of not being true to what one thinks and believes one should be.

In the next section, the problems related to the issue of individual ecological actions are discussed, and the need for a socio-political critique of many power structures is emphasized. There are profound structural problems and ethical problems related to the ways in which the division of responsibility between individuals and collectives is often presented or felt. Now, a final dimension of existential aspects is discussed here: the one related to death and finitude.

One of the big challenges related to both existential anxiety in general and to ecoanxiety in particular is the connection with death anxiety. It seems evident that this dark background is activated in people's minds in relation to ecological threats, and this often causes distancing reactions, as for example, the research in terror management theory has shown (for an insightful discussion, see Adams 2016, pp. 109-28). The author has himself written about the connections between ecotheology, death, and eco-anxiety (Pihkala 2018b). 
However, death is in itself a very tough topic to engage with, and the task of engaging with both death and eco-anxiety seems to be too much for most people, even though these topics are actually interconnected. As scholars Affifi and Christie (2018) note in their insightful study on environmental education and pedagogy of death, "Very rare is the soul who can dwell in existential angst by day and not watch Netflix at night" (p. 11).

This discussion of the existential depth of eco-anxiety is bound to be disturbing also for pastoral theologians, but it is regrettably a very necessary disturbance in the current global circumstances. The crucial thing is to understand how deep an existential crisis the ecological crisis can be for contemporary people (see also Pienaar 2011; Hickman 2020; Malcolm 2020a; for reflections by a person of color, see Heglar 2020). Pastoral care providers need to think about both the psychosocial factors that affect the people they encounter and also the possible existential dimensions of people's experiences. For example, climate guilt can be both a social, a political, a psychological, and an existential issue. Many of these existential issues can also be issues for the caregiver himself/herself, perhaps already recognized, perhaps not yet. For religious people, these existential concerns may be linked with deep spiritual and religious crises. As many texts show, people are grappling with questions about how their religion, for example, Christianity, functions in such circumstances (e.g., Malcolm 2020a; Ward 2020; McIntosh 2008). Eco-anxiety raises deep issues related to the meaning of life and the meaning in life.

However, pastoral care providers have many resources that they can develop and utilize to respond to the existential issues related to eco-anxiety. This can be conceptualized, for example, as existential resilience: the ability to withstand the existential questions arising from changing circumstances (see Foster 2015; Pihkala 2018a). The possible resources is discussed more below after the important political dimension is discussed.

\section{The Political Dimension and Justice Issues}

Eco-anxiety is furthermore complicated by the strong political character of ecological and climate issues. This character can cause hesitation in many therapists and pastoral care providers, who would not like to take political stances in their work (cf. LaMothe 2016). As for eco-anxiety itself, it is often made more difficult by social and political disputes. Anxiety is lessened if there is a feeling that the collectives around oneself are taking determined action to prepare and mitigate the threats which cause anxiety. However, unfortunately, the responses of collectives towards climate issues are often ambiguous, and sometimes, the leaders are in denial or disavowal (for a scathing critique of this, see the recent climate psychology book by Weintrobe 2021). For example, young people have often reported that their climate anxiety has grown worse because political leaders do not engage in ambitious climate politics (e.g., Hickman 2020; Jones and Davison 2021; cf. Hickman et al. 2021; Johnson and Wilkinson 2020).

Several pastoral theologians and ecotheologians have argued that Christians simply must accept the political dimension of the ecological crisis and act according to ethical values (for a wide argument about this, see LaMothe 2021c). This does not mean adhering to any one particular political party, but it does mean the demand to critically evaluate the environmental politics of various parties. The biosphere is degrading at a very alarming rate. A pioneering Lutheran ecotheologian, $\mathrm{H}$. Paul Santmire, has proposed that the climate crisis and the wider ecological crisis actually form a "status confessionis": a situation where Christians simply cannot stay passive and silent because there are too dire violations of God's will (Santmire 2020, p. 130). The concept of status confessionis has a long and partly contested history in Christian theology, and it was famously applied, for example, by Lutherans in relation to the apartheid racism in South Africa in the 1970s and 1980s (for the history of the concept, see DeJonge 2017).

There are numerous kinds of justice issues in relation to eco-anxiety. There is a tendency in various parts of the world that the most vulnerable populations are also the most susceptible to various kinds of climate-related harm. In Christian theology, the calls for "climate justice" have found deep roots in the eco-justice tendencies of ecothe- 
ology, which have been strong since the 1960s (see already the research bibliography by Bakken et al. 1995). Many proponents of ecotheology have called for justice towards both humans and non-humans (this has been especially prominent in animal theology and in posthumanism-leaning ecotheology; see, e.g., Latour 2009). Local and regional inequalities are very strong in many countries, as is discussed, for example, by environmental ethicist and theologian Jenkins (2013). In the 2000s, the movements for climate justice have been growing, and these movements have started to raise the issue that also the paralyzing forms of climate anxiety are distributed unequally (for the wide challenge of climate change and climate justice for Christian ecotheology, see Conradie and Koster 2019; for climate justice more widely, see Jafry 2019).

There are also justice issues related to the connections between climate anxiety, gender, and the legacies of racism and colonialism. In many studies, women have self-reported much more eco-anxiety than men (e.g., Hickman et al. 2021; Searle and Gow 2010). In many societies and regions, there are strong inequalities related to political power, race, and gender, which also affect climate politics and climate emotions (see, e.g., O'Dell-Chaib 2019). From the point of view of indigenous peoples, the climate crisis can appear as just a new form of oppression and suffering wrought on them by industrialized countries (e.g., Whyte 2017).

For pastoral theologians and pastoral care providers, these connections with politics and justice issues are very important to note. Many such dynamics shape people's ecoanxiety and also their attitudes towards how these issues are framed (Ray 2021). For example, in their study about climate anxiety in South Africa, Barnwell and colleagues (2020) noticed psychological impacts of climate change but also observed that many people did not resonate with the wording climate anxiety, which for them sounded more related to other people in other kinds of circumstances. There needs to be sensitivity to the wordings that are used in different contexts: sometimes such wordings as chronic stress or distress may function better than climate anxiety or eco-anxiety, and sensitivity to justice issues helps to provide recognition.

There has been much discussion in general about the question of engaging with the sources of suffering as part of the work of the therapist or the slightly different work of the pastoral care provider. Pastoral and political theologian LaMothe endorses famous therapist and social thinker Franz Fanon's approach, where the aforementioned task is seen as a crucial part of the work (LaMothe 2020, 2021a). LaMothe (2020, pp. 146-47) argues: "To fail to make the connection [between political-economic realities and the experiences of the people in therapy] would not only be unethical, because it would collude with the powers and institutions that caused suffering; it would also not be therapeutic, because it would mystify patients' suffering". In these views, the therapeutic and the political become interconnected (see also Clinebell 1996, pp. 10-11).

\section{Possibilities and Resources for Pastoral Care}

Pastoral care providers, and pastoral theologians more broadly, have many possibilities to help people channel their eco-anxiety more constructively. By engaging with the topic, pastoral theologians are at the same time dealing with their own emotions about these issues. As discussed above, the role of the caregivers is both crucial and difficult: they need to be able to notice the ways in which their own attitudes and emotions affect the pastoral care situations. On the positive side, it is an ancient truth that one may be personally helped by helping others.

Many kinds of actions, practices, and ways of non-action can give pastoral theologians resources to encounter eco-anxiety (for a review of these kinds of methods in general, see Baudon and Jachens 2021, although their use of the word "treatment" is slightly problematic in the author's view since it underscores the pathological dimensions). First, there is a need for intention and determination to work with these issues (Greenspan 2004). Because the ecological issues may feel difficult both in relation to practice and emotional life, people need both intention and support. One way forward could be to engage in a 
spiritual journey in relation to learning more about eco-anxiety and its existential challenge. With the support of natural environments, spiritual practice, and preferably trusted peers or mentors, it becomes more bearable-and more probable-to engage with dark ecoemotions. Chase (2011a, 2011b) provides resources for nature-oriented spiritual practice in relation to these themes, and Ward (2020) offers a journey of theological and emotional reflection in her monograph. Reading Ward's eco-anxiety book together with others and staying with the biblical passages quoted in the text is one possibility. For more global perspectives, the article collection edited by Malcolm (2020a) provides stories of both climate grief and courage from Christians around the world. The ancient theological method of lamenting is one resource explored in the book, together with poetry and other textual forms (see also Malcolm 2020b; Saler 2016). Methods and resources for social support are currently being researched and implemented: for example, the British Christian environmental organization GreenChristian has set up a discussion group method of encountering eco-anxiety (see Deep Waters 2022).

Second, various kinds of emotional methodologies provide support. The pastoral theologian can educate himself/herself with these and perhaps then educate others to use similar skills. There is a wide range of useful approaches, such as emotion-focused therapy (EFT, see, e.g., Greenberg 2004), Karla McLaren's emotion work methodology (McLaren 2010; for anxiety, McLaren 2020), and explicitly eco-emotional methodologies such as Joanna Macy's “The Work That Reconnects” (Macy and Brown 2014; The Work That Reconnects Network 2022) or Doppelt's (2016) transformational resilience methodology (for discussion of various eco-emotional methodologies and research about their impacts, see Hamilton 2020). Generally, developing a positive attitude towards all kinds of emotions is highly important (Greenspan 2004; Lomas 2016).

Third, methods of eco-psychology and eco-therapy provide many resources. Pastoral care providers can think critically about their own "environmental identity" (Clinebell 1996; in general, see Clayton and Opotow 2003; Doherty 2018) and utilize literature that encourages therapists to work with their own nature relationship (Lassloffy and Davis 2018; Rust 2020; for pastoral theological reflections, see also Clinebell 1996; Helsel 2018). There are both outdoor and indoor eco-psychological activities that can help with various ecoemotions (for general literature, see Jordan and Hinds 2016; Rust and Totton 2012; Buzzell and Chalquist 2009). There are creative and partly radical methodologies available, such as Trebbe Johnson's method of engaging directly with "wounded places" in more-than-human nature (Johnson 2018; Johnson 2017; for theological reflections about wounded natural places, see Stewart 2016; Pihkala 2020e). This method encourages people to be open to all kinds of emotions that environmental damage and changes may engender. There is much discussion about sadness and grief, but also about the possibility that "radical joy" may emerge through full-bodied emotional engagement (Johnson 2018; cf. Pihkala 2017a; Erickson 2020). In general, spiritual practices may help to encounter ecological grief, which is often accompanied by anxiety (Christie 2013; Menning 2017).

A special part of a holistic eco-psychological approach is one's relation to one's own body, which is the physical connecting element with the more-than-human world. Among others, Clinebell (1996) argued that a healthy relationship to the larger environment requires developing a healthy appreciation of one's body. This theme of how one regards one's body links together eco-psychology, emotion research, and wider discussions about the role of the body in Christian theology (for that wider discussion, see, e.g., Brown 2007; Isherwood and Stuart 1998). In eco-anxiety literature, the importance of many kinds of embodied practices is emphasized as means to encounter difficult emotions (e.g., Davenport 2017; Weber 2020).

Fourth, it is possible to draw from various other therapies and clinical psychology. A therapeutic approach to eco-anxiety, which takes its paralyzing potential seriously but does not pathologize it, has been developed by experienced environmental psychologist Thomas Doherty (e.g., 2018). Together with colleagues, he has recently published an overview of clinical psychology and ecological, especially climate-related concerns (Doherty et al. 2021). 
For example, acceptance and commitment therapy (ACT) can be applied to eco-anxiety (see also Feather and Williams 2022). Learning to tolerate uncertainty and ambivalence helps; this provides counter-resources to "intolerance of uncertainty", a psychological construct that is closely related to eco-anxiety (Pihkala 2020a).

In the wide literature about stronger anxiety, which often focuses on state anxiety and anxiety disorders, there are many tips and guidelines about practices that can help when such anxiety arises (for an overview of such research, see Cox and Olatunji 2019). These kinds of tips have been applied directly to eco-anxiety by some therapists and authors (see esp. Weber 2020, pp. 110-22; see also Grose 2020; Davenport 2017; Doppelt 2016).

Because of the existential dimensions of eco-anxiety, existential therapies and meaningfocused therapies can be especially helpful. Many of the authors who have written about eco-anxiety offer their versions of such approaches (see, e.g., Clinebell 1996; Doppelt 2016). The meaning-centered approach called logotherapy, developed originally by Victor Frankl, is one such approach, but meaning-focused therapies have also gained new interest and new forms in the 2000s (see, e.g., Batthyany and Russo-Netzer 2014; Hicks and Routledge 2013; Vos 2018). There is more work to do in applying the rich discussions about meaning in pastoral theology explicitly with eco-anxiety issues, and there is already some literature that applies the thoughts of classic philosophers of meaning such as Rollo May into the issues of our ecological era (e.g., Softas-Nall and Woody 2017).

Therapists Lewis et al. (2020) have recently applied dialectical thinking to the difficult questions related to eco-anxiety and ecological action, and this promising venture is given special attention here. These therapists emphasize the need to keep difficult issues dialectically open: for example, to appreciate individual actions and still emphasize the structural character of socio-ecological problems. The therapist and the client can together discuss and practice accepting ambivalence in relation to environmental responsibility: there is an ethical need to do better, but because structural problems limit the possibilities of individuals, there must be an emphasis on civil and political action towards structural change. Here, theologians may draw from various resources in Christian theology where both repentant action and acceptance of forgiveness and grace are emphasized (cf. Pihkala 2016a).

This kind of dialectical approach also enables one to explore hope while admitting that there are also feelings of despair and hopelessness. More-than-human nature can function both as a source of comfort and a source of threat; there are both certainties and uncertainties, and the social reality may be incongruent with climate reality (Lewis et al. 2020). Instead of both the listener and the client succumbing to binary thinking-which can be really tempting in the midst of anxiety-therapists and pastoral care providers should work to keep the dialectic open.

Their discussion of dialectical thinking brings reminds a theological reading of the influential "dialectical theology" in the 20th century (Karl Barth, Emil Brunner, and others). The influence of this dialectical theology extended beyond those theologians who were associated with this particular, albeit loose, school of theology. The theologians of the period between the 1910s and 1940s were hardened by the harsh reality of the two world wars, and many of the so-called "realist theologians" manifested influences from dialectical thought. Some of the theologians from these two broad schools of theology had already then environmental sensitivities (Pihkala 2017b; summary available in Pihkala 2016b). Perhaps now, when the industrialized world has had to return to the reality of suffering after a period of optimism and belief in progress since the Second World War, these earlier theologies will gain new interest and new applications in the context of eco-anxiety. There are many common tones in the therapeutic proposals by Lewis et al. (2020) and in the theologies of such figures as Daniel Day Williams, H. Richard Niebuhr, and Joseph Sittler. Naturally, these earlier theologians did not yet have climate awareness, and their thoughts also need to be augmented with more sensitivity to issues of race, gender, and postcolonialism (for the challenges of postcolonialism to spiritual care in general, see Lartey and Moon 2020). However, these theologians produced profound discussions of hope and tragedy. 
Currently, the public discussion abounds with implicit and explicit talk about the various forms of hope, despair, and hopelessness in relation to the ecological crisis and the climate crisis (for discussion of this in popular books, see, e.g., Sherrell 2021). There are naturally many stances on these issues. Some advocate for "realistic" hope, which is empathetic towards the suffering (e.g., Kelsey 2020), while others in a rather similar vein emphasize "radical hope", hoping even while there cannot be knowledge about what exactly could save the situation (this approach was championed by philosopher Jonathan Lear; see, e.g., Williston 2012). Some are more pessimistic: there are notable social movements, albeit countercultural, which base their action on the firm belief that there will be major socio-ecological collapses in the near future. Additionally, theological reflections of this vein have started to emerge (e.g., Bradford 2020; see also Robinson 2020). The members of these movements sometimes accuse other people of practicing "hopium", an addictive belief that there is still hope in the form of optimism. However, the author here joins the eco-anxiety writer Weber (2020) in his critique of both "hopium" and "reverse hopium": the latter term pointing to another form of binary thinking where it is held evident that there can be no hope.

It seems that the way forward could indeed be a dialectical one: a kind of pilgrimage that takes place between hope and hopelessness or through fluctuations of them. LaMothe, who has written in depth about the issues of hope and hopelessness amidst the ecological and political crises, champions a roughly similar view (the widest discussion of this is in LaMothe 2021c, Chp. 6). Discussing the striking book by theologian Miguel de la Torre, Theology of Hopelessness, LaMothe argues that courageous care should be the main emphasis, not hope. Drawing from philosopher Agamben's notion of inoperativity, LaMothe argues that hope could be seen as inoperative: it would not be the frame in which issues are interpreted, but rather people should practice care nevertheless. The author's own earlier emphasis on "tragic hope" (Pihkala 2017a, 2018a) and the centrality of the concept of meaning have many similarities with LaMothe's view. Quoting Kaur, LaMothe summarizes his view: "This is our defiance-to practice love even in hopelessness" (LaMothe 2021c, end of chp. 1 (LaMothe)).

Table 1 summarizes the possibilities and learning goals related to eco-anxiety, which have been explored in this article via interdisciplinary and theological research.

Table 1. Possibilities and learning goals related to eco-anxiety for pastoral theologians.

\begin{tabular}{ll}
\hline $\begin{array}{l}\text { Possibilities and Learning Goals Related to Eco-Anxiety } \\
\text { (Themes and Subthemes) }\end{array}$ & $\begin{array}{l}\text { Examples of Sources That } \\
\text { Discuss This Issue }\end{array}$ \\
\hline $\begin{array}{l}\text { Studying the various forms of eco-anxiety } \\
\text { - Understanding that eco-anxiety can be both paralyzing } \\
\text { and adaptive and learning about the empirical evidence }\end{array}$ & $\begin{array}{l}\text { (Hickman et al. 2021; } \\
\text { Wullenkord et al. 2021) }\end{array}$ \\
\hline $\begin{array}{l}\text { - Learning about various socio-ecological dynamics which } \\
\text { shape people's eco-anxiety }\end{array}$ & (Crandon et al. 2022) \\
\hline $\begin{array}{l}\text { Learning about the challenges of caregivers in relation } \\
\text { to eco-anxiety }\end{array}$ & $\begin{array}{l}\text { (Silva and Coburn 2022; } \\
\text { LaMothe 2019) }\end{array}$ \\
\hline $\begin{array}{l}\text { - Understanding dynamics related to identity, emotions, and } \\
\text { psychosocial factors }\end{array}$ & (Silva and Coburn 2022) \\
\hline - Engaging with the possible disavowal by the caregiver & (Haseley 2019) \\
\hline $\begin{array}{l}\text { - Practicing self-compassion } \\
\text { Becoming acquainted with the various existential } \\
\text { dimensions that can be linked with eco-anxiety }\end{array}$ & (Ray 2020; Brach 2019) \\
\hline
\end{tabular}


Table 1. Cont.

\begin{tabular}{|c|c|}
\hline $\begin{array}{l}\text { Possibilities and Learning Goals Related to Eco-Anxiety } \\
\text { (Themes and Subthemes) }\end{array}$ & $\begin{array}{l}\text { Examples of Sources That } \\
\text { Discuss This Issue }\end{array}$ \\
\hline $\begin{array}{l}\text { - Understanding the crucial role of responsibility and guilt } \\
\text { in relation to ecological issues }\end{array}$ & (Jensen 2019; Fredericks 2021) \\
\hline $\begin{array}{l}\text { - Understanding how death anxiety may be linked } \\
\text { with eco-anxiety }\end{array}$ & (Pihkala 2018b; Pienaar 2011) \\
\hline $\begin{array}{l}\text { - Understanding the prevalence of various forms of sadness } \\
\text { in relation to ecological changes }\end{array}$ & (Cunsolo Willox and Landman 2017) \\
\hline $\begin{array}{l}\text { Thinking critically about the political dimensions of } \\
\text { eco-anxiety and ecological issues }\end{array}$ & (LaMothe 2020, 2021a) \\
\hline $\begin{array}{l}\text { - Understanding the need to personally reflect on one's } \\
\text { attitude towards ecological action and climate politics }\end{array}$ & (LaMothe 2016) \\
\hline $\begin{array}{l}\text { - Being able to analyze political and social dynamics that } \\
\text { shape various people's experiences of eco-anxiety and their } \\
\text { preferred language about it }\end{array}$ & (Barnwell et al. 2020; Ray 2021) \\
\hline $\begin{array}{l}\text { - Understanding how factors related to gender, race, and } \\
\text { colonialism may shape people's eco-anxiety }\end{array}$ & (O’Dell-Chaib 2019; Whyte 2017) \\
\hline $\begin{array}{l}\text { Learning about various possibilities and resources for } \\
\text { encountering eco-anxiety more constructively }\end{array}$ & $\begin{array}{l}\text { (Clinebell 1996; Weber 2020; } \\
\text { Baudon and Jachens 2021) }\end{array}$ \\
\hline $\begin{array}{l}\text { - Developing an emotion-positive attitude, seeking social } \\
\text { support, and manifesting intention to work with eco-anxiety }\end{array}$ & (Greenspan 2004; McLaren 2010) \\
\hline $\begin{array}{l}\text { - Understanding how many therapeutic and psychological } \\
\text { approaches can be utilized for eco-anxiety work }\end{array}$ & $\begin{array}{l}\text { (Doherty et al. 2021; } \\
\text { Davenport 2017) }\end{array}$ \\
\hline - Learning about religious and Christian resources & $\begin{array}{l}\text { (Pihkala 2018a; Christie 2013; } \\
\text { Macy and Brown 2014) }\end{array}$ \\
\hline - Learning about emotion-focused methods & $\begin{array}{l}\text { (Hamilton 2020; Greenspan 2004; } \\
\text { McLaren 2020) }\end{array}$ \\
\hline $\begin{array}{l}\text { - Learning about and utilizing eco-psychological methods } \\
\text { and thinking about one's environmental identity }\end{array}$ & (Rust 2020; Clinebell 1996) \\
\hline $\begin{array}{l}\text { - Appreciating one's body as the connecting element with } \\
\text { the more-than-human world and using various embodied } \\
\text { activities to encounter eco-anxiety }\end{array}$ & $\begin{array}{l}\text { (Clinebell 1996; Davenport 2017; } \\
\text { Weber 2020) }\end{array}$ \\
\hline
\end{tabular}
activities to encounter eco-anxiety

- Applying dialectical thinking in relation to the difficult dynamics of the ecological crisis, such as the relationship between individual action and collective action for

(Lewis et al. 2020) structural change

- Understanding how issues of hope, despair, and hopelessness are connected with eco-anxiety

(LaMothe 2021c; Pihkala 2017a)

Understanding how eco-anxiety is connected with wider pastoral theology and ecological theology

(LaMothe 2021c; McCarroll 2020; Swain 2020)

- Realizing the connections between ecological action and eco-anxiety and the need to develop emotional resilience in environmental activism

\begin{tabular}{ll}
\hline - Understanding the ways in which rituals and spiritual & (Chase 2011a; Malcolm 2020a, \\
practices may help in encountering eco-anxiety & 2020b; Pihkala 2021) \\
\hline $\begin{array}{l}\text { - Encountering eco-anxiety in education and formation of } \\
\text { pastoral care providers }\end{array}$ & $\begin{array}{l}\text { (Calder and Morgan 2016; } \\
\text { cf. Pihkala 2020b) }\end{array}$
\end{tabular}

- Launching and supporting organizational developments such as the integration of eco-anxiety teaching in seminaries and universities

(Ray 2020; Weber 2020)

Chase 2011a; Malcolm 2020a, 2020b; Pihkala 2021)

cf. Pihkala 2020b)

(Clinebell 1996) 


\section{In Conclusions: Pastoral Theology in the Era of Eco-Anxiety}

This article has studied the challenges and possibilities related to eco-anxiety for pastoral care. Many observations have been made about therapeutic encounters in general, including various forms of spiritual care. The wider context related to pastoral theology as a whole has been much present and is given more attention in these final comments, together with its relation to eco-theology.

The recent efforts to integrate ecological theology and pastoral theology (see LaMothe 2016; McCarroll 2020; Swain 2020; cf. Clinebell 1996) are very relevant for the topic of this article. This article has focused on the emotional and psychosocial dimensions of ecological issues, but naturally, the wider spheres of action and various forms of proenvironmental behavior are interrelated with the psychological dimension. Action may help to channel eco-anxiety constructively, but if there is no space for emotion work, people may burn out (Ray 2020; Hoggett and Randall 2018; Nairn 2019). Indeed, some environmental organizations nowadays include eco-emotion workshops and support procedures in their work (see, e.g., the discussion in Weber 2020). There may thus be an element of pastoral care in the ecological activities of congregations and other collectives, and the explicit offering of such support is an important thing to consider.

In general, participating in various kinds of environmental action usually helps with various difficult eco-emotions, and there is a rich literature about various ways in which religious communities can participate in this (see, for example, the materials produced by ecumenical and denominational environmental movements, such as Laudato $\mathrm{Si}^{\prime}$ Movement 2022; A Rocha 2022; World Council of Churches 2022). The potential strengths and challenges for various denominations in encountering eco-anxiety is a topic for future research (for some reflections on certain denominations, see Pihkala 2016a; Ward 2020).

Various kinds of rituals can be organized in relation to eco-anxiety and other ecoemotions (Pihkala 2021), and sometimes, rituals related to ecological concerns have implicit dimensions related to the processing of eco-emotions (cf. Fredericks 2021). While these rituals are maybe not pastoral care per se, if the caregiver is aware of these kinds of methods, they can be recommended to people on suitable occasions. Engaging in spiritual practices can help both the caregiver and the "client" to process their eco-anxiety (cf. Malcolm 2020b). The author has written elsewhere of the need for religious leaders to work critically with eco-guilt, eco-anger, and ecological grief and sadness in spiritual care, rituals, and wider action (Pihkala 2022b). Case examples in English are available, for example, about ways to encounter ecological shame via creative Christian worship (Powell 2019) or ecological grief via outdoor spiritual practices (Hirschfeld and Blackmer 2021; see also many articles in Malcolm 2020a).

The education and formation of pastoral care providers is an area that needs attention in relation to eco-anxiety. First of all, many who undergo such training are young of age, and many of them feel eco-anxiety in some form. They require support from their teachers (cf. Pihkala 2020b). Second, students can be taught constructive ways to encounter eco-anxiety, as has been the aim in Calder and Morgan's pioneering approach (Calder and Morgan 2016). Teaching about eco-anxiety and eco-emotions should be included in theological seminaries and universities. Furthermore, pastors, counselors, and other providers of pastoral care may find it difficult to devote time to learn more about contemporary issues such as eco-anxiety in the midst of their daily life and work. One potential means to help in this is to organize workshops where various professionals focus on environmental issues, including their emotional dimension. Various frameworks have been applied to the process of transformation of identity and attitudes that the ecological crisis requires, such as the "ecological conversion" championed by Francis (2015) and the "affective transformation" delineated by environmental scholar Verlie (2022).

It is notable that anxiety researcher and philosopher Kurth (2018) discusses the positive sides of anxiety often through the examples of religious figures, such as John Woolman and Martin Luther King. Kurth points out that it was exactly anxiety that caused these people to act: they felt problematic uncertainty about moral issues, and this anxiety did not let them 
go. They were able to cultivate anxiety as a moral emotion and not to stifle it or run away from it. This dynamic can be the positive power of eco-anxiety: if it does not become too intense, it causes people to "stay with the trouble" (see Haraway 2016) and search for ways to practice morality and responsibility, even amidst ambiguous circumstances. Religions may offer people sources of existential resilience, which help to bear eco-anxiety, but this needs effort and intention since religion can also become a hiding place from the troubles of the world.

Funding: This research was supported by a personal grant from Finnish Cultural Foundation, granted in February 2019 (no grant number given).

Institutional Review Board Statement: Not applicable.

Informed Consent Statement: Not applicable.

Data Availability Statement: Not applicable.

Acknowledgments: The author expresses gratitude to the two anonymous peer reviewers for their feedback about how to improve the article.

Conflicts of Interest: The author declares no conflict of interest. The funders had no role in the design of the study; in the collection, analyses, or interpretation of data; in the writing of the manuscript, or in the decision to publish the results.

\section{Notes}

1 There are several more research articles about eco-anxiety and existential issues currently either in press or in peer review. See, for example, the two forthcoming books edited by Douglas Vakoch and Sam Mickey, Climate Psychology in a Pandemic: Environmental Health in Lockdown and Eco-Anxiety and Planetary Hope: The Experience of COVID-19 and the Climate Crisis.

\section{References}

A Rocha International. 2022. Available online: https://www.arocha.org/en/ (accessed on 17 February 2022).

Adams, Matthew. 2016. Ecological Crisis, Sustainability and the Psychosocial Subject: Beyond Behaviour Change. London: Palgrave Macmillan.

Affifi, Ramsey, and Beth Christie. 2018. Facing Loss: Pedagogy of Death. Environmental Education Research 25: 1143-57. [CrossRef]

Albrecht, Glenn. 2011. Chronic Environmental Change: Emerging 'Psychoterratic' Syndromes. In Climate Change and Human Well-Being: Global Challenges and Opportunities. Edited by Inka Weissbecker. New York: Springer, pp. 43-56.

Albrecht, Glenn. 2019. Earth Emotions: New Words for a New World. Ithaca: Cornell University Press.

Andrews, Nadine, and Paul Hoggett. 2019. Facing up to Ecological Crisis: A Psychosocial Perspective from Climate Psychology. In Facing Up to Climate Reality: Honesty, Disaster and Hope. Edited by John Foster. London: Green House Publishing, pp. 155-71.

Antadze, Nino. 2020. Moral Outrage as the Emotional Response to Climate Injustice. Environmental Justice 13: 21-26. [CrossRef]

Bakken, Peter W., Joan Gibb Engel, and J. Ronald Engel. 1995. Ecology, Justice, and Christian Faith: A Critical Guide to the Literature. Westport: Greenwood Publishing Group.

Barlow, David H. 2004. Anxiety and Its Disorders: The Nature and Treatment of Anxiety and Panic, 2nd ed. New York: Guilford Press.

Barnwell, Garret, Louise Stroud, and Mark Watson. 2020. Critical Reflections from South Africa: Using the Power Threat Meaning Framework to Place Climate-Related Distress in Its Socio-Political Context. Clinical Psychology Forum 332: 7-15.

Batthyany, Alexander, and Pninit Russo-Netzer, eds. 2014. Meaning in Positive and Existential Psychology, 1st ed. New York: Springer. [CrossRef]

Baudon, Pauline, and Liza Jachens. 2021. A Scoping Review of Interventions for the Treatment of Eco-Anxiety. International Journal of Environmental Research and Public Health 18: 9636. [CrossRef]

Brach, Tara. 2019. Radical Compassion: Learning to Love Yourself and Your World with the Practice of RAIN. New York: Penguin Books.

Bradford, David T. 2020. Spiritual Life on a Burning Planet: A Christian Response to Climate Change. Eugene: Wipf and Stock.

Bradley, Graham L., and Joseph P. Reser. 2017. Adaptation Processes in the Context of Climate Change: A Social and Environmental Psychology Perspective. Journal of Bioeconomics 19: 29-51. [CrossRef]

Brown, David. 2007. God and Grace of Body: Sacrament in Ordinary. London: Oxford University Press.

Budziszewska, Magdalena, and Sofia Elisabet Jonsson. 2021. From Climate Anxiety to Climate Action: An Existential Perspective on Climate Change Concerns Within Psychotherapy. The Journal of Humanistic Psychology 61. [CrossRef]

Buzzell, Linda, and Craig Chalquist. 2009. Ecotherapy: Healing with Nature in Mind. San Francisco: Sierra Club Books.

Calder, Andy S., and Jan E. Morgan. 2016. 'Out of the Whirlwind': Clinical Pastoral Education and Climate Change. Journal of Pastoral Care $\mathcal{E}$ Counseling 70: 16-25. [CrossRef]

Chase, Steven. 2011a. A Field Guide to Nature as Spiritual Practice. Grand Rapids: W.B. Eerdmans Pub. 
Chase, Steven. 2011b. Nature as Spiritual Practice. Grand Rapids: Eerdmans.

Christie, Douglas E. 2013. The Blue Sapphire of the Mind: Notes for a Contemplative Ecology. New York: Oxford University Press.

Clayton, Susan. 2020. Climate Anxiety: Psychological Responses to Climate Change. Journal of Anxiety Disorders 74: 102263. [CrossRef]

Clayton, Susan D., and Christie Manning, eds. 2018. Psychology and Climate Change: Human Perceptions, Impacts, and Responses. London: Academic Press (Elsevier).

Clayton, Susan, and Susan Opotow, eds. 2003. Identity and the Natural Environment: The Psychological Significance of Nature. Cambridge: MIT Press.

Clinebell, Howard John. 1996. Ecotherapy: Healing Ourselves, Healing the Earth: A Guide to Ecologically Grounded Personality Theory, Spirituality, Therapy, and Education. Minneapolis: Fortress Press.

Comtesse, Hannah, Verena Ertl, Sophie M. C. Hengst, Rita Rosner, and Geert E. Smid. 2021. Ecological Grief as a Response to Environmental Change: A Mental Health Risk or Functional Response? International Journal of Environmental Research and Public Health 18: 734. [CrossRef]

Conradie, Ernst M., and Hilda P. Koster, eds. 2019. TET Clark Handbook of Christian Theology and Climate Change. London: Bloomsbury Publishing Plc.

Cox, Rebecca C., and Bunmi O. Olatunji. 2019. Anxiety and Related Disorders: An Introduction. In The Cambridge Handbook of Anxiety and Related Disorders. Edited by Bunmi O. Olatunji. Cambridge Handbooks in Psychology. Cambridge: Cambridge University Press, pp. 1-10. [CrossRef]

Crandon, Tara J., James G. Scott, Fiona J. Charlson, and Hannah J. Thomas. 2022. A Social-Ecological Perspective on Climate Anxiety in Children and Adolescents. Nature Climate Change 12: 123-31. [CrossRef]

Cunsolo, Ashlee, Sherilee L. Harper, Kelton Minor, Katie Hayes, Kimberly G. Williams, and Courtney Howard. 2020. Ecological Grief and Anxiety: The Start of a Healthy Response to Climate Change? The Lancet Planetary Health 4: e261-63. [CrossRef]

Cunsolo Willox, Ashlee, and Neville R. Ellis. 2018. Ecological Grief as a Mental Health Response to Climate Change-Related Loss. Nature Climate Change 8: 275-81. [CrossRef]

Cunsolo Willox, Ashlee, and Karen Landman, eds. 2017. Mourning Nature: Hope at the Heart of Ecological Loss $\mathcal{E}$ Grief. Montreal and Kingston: McGill-Queen's University Press.

Davenport, Leslie. 2017. Emotional Resiliency in the Era of Climate Change: A Clinician's Guide. London: Jessica Kingsley Publishers.

Deep Waters: A Project of Borrowed Time. 2022. Available online: https://greenchristian.org.uk/deep-waters-a-project-of-borrowedtime/ (accessed on 17 February 2022).

DeJonge, Michael P. 2017. Bonhoeffer, Status Confessionis, and the Lutheran Tradition. Stellenbosch Theological Journal 3: 41-60. [CrossRef]

Doherty, Thomas J. 2018. Individual Impacts and Resilience. In Psychology and Climate Change: Human Perceptions, Impacts, and Responses. Edited by Susan D. Clayton and Christie M. Manning. Amsterdam: Academic Press, pp. 245-66.

Doherty, Thomas J., and Susan Clayton. 2011. The Psychological Impacts of Global Climate Change. Edited by Susan Clayton. American Psychologist 66: 265-76. [CrossRef]

Doherty, Thomas J., Amy Lykins, Nancy A. Piotrowski, Zoey Rogers, Derrick D. Sebree, and Kristi E. White. 2021. Clinical Psychology Responses to the Climate Crisis. In Reference Module in Neuroscience and Biobehavioral Psychology. Amsterdam: Elsevier. [CrossRef]

Doppelt, Bob. 2016. Transformational Resilience: How Building Human Resilience to Climate Disruption Can Safeguard Society and Increase Wellbeing. Saltaire: Taylor \& Francis.

Erickson, Jacob. 2020. Grief and New Creation: Theopoetics for a Pandemic. Dialog: A Journal of Theology 59: 73-74. [CrossRef]

Feather, Gabrielle, and Matt Williams. 2022. The Moderating Effects of Psychological Flexibility and Psychological Inflexibility on the Relationship between Climate Concern and Climate-Related Distress. Journal of Contextual Behavioral Science 23: 137-43. [CrossRef]

Foster, John. 2015. After Sustainability: Denial, Hope, Retrieval. London and New York: Routledge.

Francis, Pope. 2015. Laudato Si': On Care for Our Common Home. Vatican: Vatican Press.

Fredericks, Sarah E. 2021. Environmental Guilt and Shame: Signals of Individual and Collective Responsibility and the Need for Ritual Responses. London: Oxford University Press.

Gillespie, Sally. 2020. Climate Crisis and Consciousness: Re-Imagining Our World and Ourselves. London and New York: Routledge.

Greenberg, Leslie S. 2004. Emotion-Focused Therapy. Clinical Psychology \& Psychotherapy: An International Journal of Theory E Practice 11: $3-16$.

Greenspan, Miriam. 2004. Healing through the Dark Emotions: The Wisdom of Grief, Fear, and Despair. Boulder: Shambhala.

Grose, Anouchka. 2020. A Guide to Eco-Anxiety: How to Protect the Planet and Your Mental Health. London: Watkins.

Grupe, Dan W., and Jack B. Nitschke. 2013. Uncertainty and Anticipation in Anxiety: An Integrated Neurobiological and Psychological Perspective. Nature Reviews Neuroscience 14: 488-501. [CrossRef]

Haraway, Donna J. 2016. Staying with the Trouble: Making Kin in the Chthulucene. Experimental Futures. Durham: Duke University Press.

Haltinner, Kristin, and Dilshani Sarathchandra. 2018. Climate Change Skepticism as a Psychological Coping Strategy. Sociology Compass 12: e12586. [CrossRef] 
Hamilton, Jo. 2020. Emotional Methodologies for Climate Change Engagement: Towards an Understanding of Emotion in Civil Society Organisation (CSO)-Public Engagements in the UK. Doctor of Philosophy dissertation, University of Reading, Reading, UK. Available online: http:/ / centaur.reading.ac.uk/95647/3/23861657_Hamilton_Thesis_Redacted.pdf (accessed on 17 February 2022).

Haseley, Dennis. 2019. Climate Change: Clinical Considerations. International Journal of Applied Psychoanalytic Studies 16: 109-15. [CrossRef]

Heglar, Mary Annaïse. 2020. Climate Change Isn't the First Existential Threat. Medium. February 18. Available online: https://zora. medium.com/sorry-yall-but-climate-change-ain-t-the-first-existential-threat-b3c999267aa0 (accessed on 17 February 2022).

Helsel, Philip Browning. 2018. Loving The World: Place Attachment and Environment in Pastoral Theology. Journal of Pastoral Theology 28: 22-33. [CrossRef]

Hickman, Caroline. 2020. We Need to (Find a Way to) Talk about ... Eco-Anxiety. Journal of Social Work Practice 34: 411-24. [CrossRef]

Hickman, Caroline, Elizabeth Marks, Panu Pihkala, Susan Clayton, R. Eric Lewandowski, Elouise E. Mayall, Britt Wray, Catriona Mellor, and Lise van Susteren. 2021. Climate Anxiety in Children and Young People and Their Beliefs about Government Responses to Climate Change: A Global Survey. The Lancet Planetary Health 5: e863-73. [CrossRef]

Hicks, Joshua A., and Clay Routledge, eds. 2013. The Experience of Meaning in Life: Classical Perspectives, Emerging Themes, and Controversies. Dordrecht: Springer.

Hirschfeld, A. Robert, and Stephen Blackmer. 2021. Beyond Acedia and Wrath: Life during the Climate Apocalypse. Anglican Theological Review 103: 196-207. [CrossRef]

Hoggett, Paul, and Rosemary Randall. 2018. Engaging with Climate Change: Comparing the Cultures of Science and Activism. Environmental Values 27: 223-43. [CrossRef]

Isherwood, Lisa, and Elizabeth Stuart. 1998. Introducing Body Theology. Introductions in Feminist Theology. Sheffield: Sheffield Academic Press.

Jafry, Tahseen, ed. 2019. Routledge Handbook of Climate Justice. London and New York: Routledge, Taylor \& Francis Group.

Jamail, Dahr. 2019. End of Ice: Bearing Witness and Finding Meaning in the Path of Climate Disruption. New York: The New Press.

Jenkins, Willis. 2013. The Future of Ethics: Sustainability, Social Justice, and Religious Creativity. Washington, DC: Georgetown University Press.

Jensen, Tim. 2019. Ecologies of Guilt in Environmental Rhetorics. Palgrave Studies in Media and Environmental Communication. Cham: Palgrave Macmillan.

Johnson, Trebbe. 2017. 101 Ways to Make Guerrilla Beauty. Radjoy Press.

Johnson, Trebbe. 2018. Radical Joy for Hard Times: Finding Meaning and Makin Beauty in Earth's Broken Places. Berkeley: North Atlantic Books.

Johnson, Ayana Elizabeth, and Katharine K. Wilkinson, eds. 2020. All We Can Save: Truth, Courage, and Solutions for the Climate Crisis. New York: One World.

Jones, Charlotte A., and Aidan Davison. 2021. Disempowering Emotions: The Role of Educational Experiences in Social Responses to Climate Change. Geoforum 118: 190-200. [CrossRef]

Jordan, Martin, and Joe Hinds, eds. 2016. Ecotherapy: Theory, Research and Practice. London: Palgrave.

Joyce, Cullan. 2020. Responses to Apocalypse: Early Christianity and Extinction Rebellion. Religions 11: 384. [CrossRef]

Jylhä, Kirsti M. 2017. Denial Versus Reality of Climate Change. In Encyclopedia Of The Anthropocene. Edited by Dominick A. DellaSala and Michael I. Goldstein. Amsterdam: Elsevier, pp. 487-92. [CrossRef]

Kelsey, Elin. 2020. Hope Matters: Why Changing the Way We Think Is Critical to Solving the Environmental Crisis. Vancouver and Berkeley: Greystone Books.

Kretz, Lisa. 2017. Emotional Solidarity: Ecological Emotional Outlaws Mourning Environmental Loss and Empowering Positive Change. In Mourning Nature: Hope at the Heart of Ecological Loss \& Grief. Edited by Ashlee Cunsolo Willox and Karen Landman. Montreal and Kingston: McGill-Queen's University Press, pp. 258-91.

Kurth, Charlie. 2018. The Anxious Mind: An Investigation into the Varieties and Virtues of Anxiety. Cambridge: The MIT Press.

Laudato Si' Movement. 2022. Available online: https:/ / laudatosimovement.org/ (accessed on 17 February 2022).

LaMothe, Ryan. 2016. This Changes Everything: The Sixth Extinction and Its Implications for Pastoral Theology. Journal of Pastoral Theology 26: 178-94. [CrossRef]

LaMothe, Ryan. 2019. Giving Counsel in a Neoliberal-Anthropocene Age. Pastoral Psychology 68: 421-36. [CrossRef]

LaMothe, Ryan. 2020. On Being at Home in the World: A Psychoanalytic-Political Perspective on Dwelling in the Anthropocene Era. The Psychoanalytic Review 107: 123-51. [CrossRef]

LaMothe, Ryan. 2021a. Illusions, Political Selves, and Responses to the Anthropocene Age: A Political-Psychoanalytic Perspective. Free Associations 84: 1-18. [CrossRef]

LaMothe, Ryan. 2021b. A Radical Pastoral Theology for the Anthropocene Era: Thinking and Being Otherwise. Journal of Pastoral Theology 31: 54-74. [CrossRef]

LaMothe, Ryan. 2021c. Radical Political Theology for the Anthropocene Era. Eugene: Wipf and Stock.

Lartey, Emmanuel Y., and Hellena Moon, eds. 2020. Postcolonial Images of Spiritual Care. Eugene: Wipf and Stock.

Lassloffy, Tracey A., and Sean D. Davis. 2018. Nurturing Nature: Exploring Ecological Self-of-the-Therapist Issues. Journal of Marital and Family Therapy 45: 176-85. [CrossRef] [PubMed] 
Latour, Bruno. 2009. Will Non-Humans Be Saved? An Argument in Ecotheology. Journal of the Royal Anthropological Institute 15: 459-75. [CrossRef]

LeDoux, Joseph. 2016. Anxious: Using the Brain to Understand and Treat Fear and Anxiety. New York: Penguin Books.

Lewis, Janet, Elizabeth Haase, and Alexander Trope. 2020. Climate Dialectics in Psychotherapy: Holding Open the Space between Abyss and Advance. Psychodynamic Psychiatry 48: 271-94. [CrossRef] [PubMed]

Lomas, Tim. 2016. The Positive Power of Negative Emotions: How Harnessing Your Darker Feelings Can Help You See a Brighter Dawn. London: Piatkus.

Macy, Joanna. 1995. Working through Environmental Despair. In Ecopsychology: Restoring the Earth, Healing the Mind. Edited by Theodore Roszak, Mary E. Gomes and Allen D. Kanner. San Francisco: Sierra Club, pp. 240-69.

Macy, Joanna, and Molly Young Brown. 2014. Coming Back to Life: The Updated Guide to the Work That Reconnects. Gabriola Island: New Society Publishers.

Malcolm, Hannah, ed. 2020a. Words for a Dying World: Stories of Grief and Courage from the Global Church. London: SCM Press.

Malcolm, Hannah. 2020b. Grieving the Earth as Prayer. The Ecumenical Review 72: 581-95. [CrossRef]

Marshall, George. 2015. Don't Even Think about It: Why Our Brains Are Wired to Ignore Climate Change. New York: Bloomsbury Publishing USA.

McCarroll, Pamela R. 2020. Listening for the Cries of the Earth: Practical Theology in the Anthropocene. International Journal of Practical Theology 24: 29-46. [CrossRef]

McIntosh, Alastair. 2008. Hell and High Water: Climate Change, Hope and the Human Condition. Edinburgh: Birlinn.

McLaren, Karla. 2010. The Language of Emotions: What Your Feelings Are Trying to Tell You. Boulder: Sounds True.

McLaren, Karla. 2020. Embracing Anxiety: How to Access the Genius inside This Vital Emotion. Boulder: Sounds True.

Menning, Nancy. 2017. Environmental Mourning and the Religious Imagination. In Mourning Nature: Hope at the Heart of Ecological Loss \& Grief. Edited by Ashlee Cunsolo Willox and Karen Landman. Montreal and Kingston: McGill-Queen's University Press, pp. 39-63.

Mkono, Mucha. 2020. Eco-Hypocrisy and Inauthenticity: Criticisms and Confessions of the Eco-Conscious Tourist/Traveller. Annals of Tourism Research 84: 102967. [CrossRef]

Nairn, Karen. 2019. Learning from Young People Engaged in Climate Activism: The Potential of Collectivizing Despair and Hope. Young 27: 435-50. [CrossRef]

O'Dell-Chaib, Courtney. 2019. Desiring Devastated Landscapes: Love After Ecological Collapse. Doctor of Philosophy in Religion dissertation, Syracuse University, New York, NY, USA. Available online: https://surface.syr.edu/etd/1045/ (accessed on 17 February 2022).

Ojala, Maria, Ashlee Cunsolo, Charles A. Ogunbode, and Jacqueline Middleton. 2021. Anxiety, Worry, and Grief in a Time of Environmental and Climate Crisis: A Narrative Review. Annual Review of Environment and Resources 46: 35-58. [CrossRef]

Orange, Donna. 2017. Climate Change, Psychoanalysis, and Radical Ethics. New York: Routledge.

Passmore, Holli-Anne, and Andrew J. Howell. 2014. Eco-Existential Positive Psychology: How Experiences in Nature Can Address Our Existential Anxieties and Contribute to Well-Being. The Humanist Psychologist 42: 370-88. [CrossRef]

Patel, Gopal D. 2020. Hindu Approaches to Climate Trauma. In Hindu Approaches to Spiritual Care: Chaplaincy in Theory and Practice. Edited by Vineet Chander and Lucinda Mosher. London: Jessica Kingsley Publishers, pp. 261-68.

Pew Research Center. 2021. Climate Change Concerns Make Many Around the World Willing to Alter How They Live and Work. Pew Research Center's Global Attitudes Project, September 14. Available online: https:/ /www.pewresearch.org/global/2021/09/14/inresponse-to-climate-change-citizens-in-advanced-economies-are-willing-to-alter-how-they-live-and-work/ (accessed on 17 February 2022).

Pienaar, Mariska. 2011. An Eco-Existential Understanding of Time and Psychological Defenses: Threats to the Environment and Implications for Psychotherapy. Ecopsychology 3: 25-39. [CrossRef]

Pihkala, Panu. 2016a. The Pastoral Challenge of the Eco-Reformation: Environmental Anxiety and Lutheran 'Eco-Reformation'. Dialog: A Journal of Theology 55: 131-40. [CrossRef]

Pihkala, Panu. 2016b. Rediscovery of Early Twentieth-Century Ecotheology. Open Theology 2: 268-85. [CrossRef]

Pihkala, Panu. 2017a. Environmental Education After Sustainability: Hope in the Midst of Tragedy. Global Discourse 7: 109-27. [CrossRef]

Pihkala, Panu. 2017b. Early Ecotheology and Joseph Sittler. Studies in Religion and the Environment. Zürich: LIT Verlag.

Pihkala, Panu. 2018a. Eco-anxiety, Tragedy, and Hope: Psychological and Spiritual Dimensions of Climate Change. Zygon 53: 545-69. [CrossRef]

Pihkala, Panu. 2018b. Death, the Environment, and Theology. Dialog 57: 287-94. [CrossRef]

Pihkala, Panu. 2020a. Anxiety and the Ecological Crisis: An Analysis of Eco-Anxiety and Climate Anxiety. Sustainability $12: 7836$. [CrossRef]

Pihkala, Panu. 2020b. Theology of 'Eco-Anxiety' as Liberating Contextual Theology. In Contextual Theology: Skills and Practices of Liberating Faith. Edited by Sigurd Bergmann and Mika Vähäkangas. New York: Routledge, pp. 181-204.

Pihkala, Panu. 2020c. Eco-Anxiety and Environmental Education. Sustainability 12: 10149. [CrossRef] 
Pihkala, Panu. 2020d. The Cost of Bearing Witness to the Environmental Crisis: Vicarious Traumatization and Dealing with Secondary Traumatic Stress among Environmental Researchers. Social Epistemology: The Cost of Bearing Witness: Secondary Trauma and Self-Care in Fieldwork-Based Social Research; Guest Editors: Nena Močnik and Ahmad Ghouri 34: 86-100. [CrossRef]

Pihkala, Panu. 2020e. Ritualizing Grief. In Words for a Dying World: Stories of Grief and Courage from the Global Church. Edited by Hannah Malcolm. London: SCM Press, pp. 167-72.

Pihkala, Panu. 2021. Ympäristöahdistus ja rituaalit: Analyysia ympäristötunteiden rituaalisesta käsittelystä [Eco-anxiety and Rituals: An analysis of methods for encountering eco-emotions ritually]. Uskonnontutkija Religionsforskaren 10. [CrossRef]

Pihkala, Panu. 2022a. Toward a Taxonomy of Climate Emotions. Frontiers in Climate 3: 199. [CrossRef]

Pihkala, Panu. 2022b. Religious Communities and Climate Emotions: Encountering Climate Grief, Guilt, and Anger. In Brooding Over Creation: Affective Ecologies, Religion, and Theology. Edited by Jacob Erickson. London: Bloomsbury, Forthcoming.

Powell, Russell C. 2019. Shame, Moral Motivation, and Climate Change. Worldviews 23: 230-53. [CrossRef]

Ray, Sarah Jacquette. 2020. A Field Guide to Climate Anxiety: How to Keep Your Cool on a Warming Planet. Oakland: University of California Press.

Ray, Sarah Jaquette. 2021. Who Feels Climate Anxiety? The Cairo Review of Global Affairs. No. 43 (Fall 2021). Available online: https:/ / www.thecairoreview.com/home-page/who-feels-climate-anxiety/ (accessed on 17 February 2022).

Robinson, Timothy. 2020. Reimagining Christian Hope(Lessness) in the Anthropocene. Religions 11: 192. [CrossRef]

Rust, Mary-Jayne. 2020. Towards an Ecopsychotherapy. London: Confer Books.

Rust, Mary-Jayne, and Nick Totton, eds. 2012. Vital Signs: Psychological Responses to Ecological Crisis. London: Karnac.

Saler, Robert C. 2016. Pastoral Care and Ecological Devastation: Un-Interpreting the Silence. Journal of Lutheran Ethics. 16. Available online: https:/ / elca.org/JLE/Articles/1140 (accessed on 17 February 2022).

Santmire, H. Paul. 2020. Celebrating Nature by Faith: Studies in Reformation Theology in an Era of Global Emergency. Eugene: Cascade.

Scott, Brandon G., and Carl F. Weems. 2013. Natural Disasters and Existential Concerns: A Test of Tillich's Theory of Existential Anxiety. Journal of Humanistic Psychology 53: 114-28. [CrossRef]

Seaman, Elizabeth B. 2016. Climate Change on the Therapist's Couch: How Mental Health Clinicians Receive and Respond to Indirect Psychological Impacts of Climate Change in the Therapeutic Setting. Theses, Dissertations, and Projects 1736. Northampton: Smith College for Social Work. Available online: https: / / scholarworks.smith.edu/theses/1736 (accessed on 17 February 2022).

Searle, Kristina, and Kathryn Gow. 2010. Do Concerns about Climate Change Lead to Distress? International Journal of Climate Change Strategies and Management 2: 362-79. [CrossRef]

Sherrell, Daniel. 2021. Warmth: Coming of Age at the End of the World. New York: Penguin Books.

Silva, Jules F. B., and Jennifer Coburn. 2022. Therapists' Experience of Climate Change: A Dialectic between Personal and Professional. Counselling and Psychotherapy Research. [CrossRef]

Softas-Nall, Sofia, and William Douglas Woody. 2017. The Loss of Human Connection to Nature: Revitalizing Selfhood and Meaning in Life through the Ideas of Rollo May. Ecopsychology 9: 241-52. [CrossRef]

Steffen, Will, Katherine Richardson, Johan Rockström, Sarah E. Cornell, Ingo Fetzer, Elena Bennett, Reinette Biggs, and de Vries Wim. 2015. Planetary Boundaries: Guiding Human Development on a Changing Planet. Science 347: 1259855. [CrossRef]

Stewart, Benjamin M. 2016. What's the Right Rite? Treating Environmental Degradation as Sickness or Sin. Currents in Theology and Mission (Online) 43: 3-8.

Stoknes, Per Espen. 2015. What We Think About When We Try Not To Think About Global Warming: Toward a New Psychology of Climate Action. White River Junction: Chelsea Green Publishing.

Swain, Storm. 2020. Climate Change and Pastoral Theology. In TET Clark Handbook of Christian Theology and Climate Change. Edited by Ernst M. Conradie and Hilda P. Koster. London: T\&T Clark, pp. 615-26.

Taylor, Steven. 2020. Anxiety Disorders, Climate Change, and the Challenges Ahead: Introduction to the Special Issue. Journal of Anxiety Disorders 76: 102313. [CrossRef]

The Work That Reconnects Network. 2022. Available online: https:/ / workthatreconnects.org/ (accessed on 17 February 2022).

Tillich, Paul. 1952. The Courage to Be. New Haven: Yale University Press.

Tillich, Paul. 1963. Man and Earth. In The Eternal Now: Sermons. London: SCM Press, pp. 54-64.

Tschakert, Petra, Neville R. Ellis, C. Anderson, A. Kelly, and J. Obeng. 2019. One Thousand Ways to Experience Loss: A Systematic Analysis of Climate-Related Intangible Harm from around the World. Global Environmental Change 55: 58-72. [CrossRef]

Verlie, Blanche. 2022. Learning to Live with Climate Change: From Anxiety to Transformation. Routledge Focus. London: Routledge.

Verplanken, Bas, Elizabeth Marks, and Alexandru I. Dobromir. 2020. On the Nature of Eco-Anxiety: How Constructive or Unconstructive Is Habitual Worry about Global Warming? Journal of Environmental Psychology 72: 101528. [CrossRef]

Vos, Joel. 2018. Meaning in Life: An Evidence-Based Handbook for Practitioners. London: Bloomsbury.

Ward, Frances. 2020. Like There's No Tomorrow: Climate Crisis, Eco-Anxiety and God. Durham: Sacristy Press.

Wardell, Susan. 2020. Naming and Framing Ecological Distress. Medicine Anthropology Theory 7: 187-201. [CrossRef]

Weber, Jack Adam. 2020. Climate Cure: Heal Yourself to Heal the Planet. Woodbury: Llewellyn Publications.

Weintrobe, Sally. 2021. Psychological Roots of the Climate Crisis: Neoliberal Exceptionalism and the Culture of Uncare. New York: Bloomsbury.

Whyte, Kyle Powys. 2017. Is It Colonial Déjà vu? Indigenous Peoples and Climate Injustice. In Humanities for the Environment: Integrating Knowledge, Forging New Constellations of Practice. Edited by Joni Adamson and Michael Davis. London and New York: Routledge, pp. 88-104. 
Williston, Byron. 2012. Climate Change and Radical Hope. Ethics \& the Environment 17: 165-86.

Woodbury, Zhiva. 2019. Climate Trauma: Toward a New Taxonomy of Trauma. Ecopsychology 11: 1-8. [CrossRef]

World Council of Churches. 2022. Care for Creation and Climate Justice. Available online: https://www.oikoumene.org/what-we-do/ care-for-creation-and-climate-justice (accessed on 17 February 2022).

Wullenkord, Marlis, Josephine Tröger, Karen Hamann, Laura Loy, and Gerhard Reese. 2021. Anxiety and Climate Change: A Validation of the Climate Anxiety Scale in a German-Speaking Quota Sample and an Investigation of Psychological Correlates. Climatic Change 168: 1-23. [CrossRef]

Yalom, Irvin D. 1980. Existential Psychotherapy. New York: Basic Books. 